Sanja Petronić ${ }^{7}$, Meri Burzić ${ }^{7}$, Dubravka Milovanović ${ }^{2}$, Katarina Čolić ${ }^{7}$,̌eljko Radovanović ${ }^{3}$

\title{
Picosecond laser shock peening of base Nimonic 263 material and laser welded Nimonic 263 alloy
}

\section{Mehanička obrada pikosekundnim laserom osnovnog materijala i zavarenih spojeva legure Nimonik 263}

\author{
Originalni naučni rad / Original scientific paper \\ UDK / UDC: 621.791.725
}

Rad primljen / Paper received:

Oktobar 2015.

Kljucne reči: zavarivanje laserom, obrada laserom, ispitivanje zatezanjem, mikrostruktura,superlegura $\mathrm{Ni}$

\author{
Adresa autora / Author's address: \\ ${ }^{1}$ Inovacioni centar Mainskkog fakulteta u Beogradu, Beograd, \\ Srbija \\ 2 Institut za nuklearne nauke "Vinča", Srbija \\ 3 Tehnološko-metalurški fakultet Univeriteta u Beogradu, \\ Beograd, Srbija
}

Key words: laser welding, laser treatment, tensile testing, microstructure, superalloy $\mathrm{Ni}$

\section{Izvod}

Lasersko zavarivanje je proces zavarivanja sa velikom gustinom energije i mnogobrojnim prednostima u odnosu na konvencionalne metode zavarivanja (uska zona uticaja toplote, manji unos toplote, manja distorzija i sl.) Mehanička obrada laserom je inovativna tehnika kojom se poboljšavaju karakteristike otpornosti na zamor, habanje $\mathrm{i}$ otpornost na koroziju. $\mathrm{U}$ ovom radu, mehanički su obrađene laserom dve grupe uzoraka; osnovnog materijala i laserski zavarenih spojeva. Limovi superlegure debljine $2 \mathrm{~mm}$ su zavareni milisekundnim Nd:YAG laserom, dok je mehanička obada obavljena pikosekundnim $\mathrm{Nd}$ :YAG laserom. Zavareni spojevi su ispitani zatezanjem, a mikrostruktura je posmatrana optičkim i skenirajućim elektronskim mikroskopom. Mikrotvrdoća je merena po Vikersu sa opterećenjem od $10 \mathrm{~N}$.

automatizacije, mogućnost zavarivanja debelih preska u jednom prolazu i poboljšanu fleksibilnost dizajna [4-8]. Jedna od mnogih karakteristika laserskog zavarivanja je sposobnost zavarivanja bez dodatnog materijala. Mehanička obrada laserom (laser shock peening) je, za razliku od laserskog zavarivanja, mehanička obrada bez topljenja materijala. Ovom obradom se poboljšavaju karakteristike zamora materijala, otpornost na interkristalnu koroziju, otpornost na habanje i oksidaciju, kao i mehaničke osobine materijala. Ako se mehanička obrada laserom uspešno primenjuje, performanse zamora metalnih 
komponenti mogu da se znatno povećaju zahvaljujući prisustvu pritisnih zaostalih napona $u$ materijalu [9-13]. Limovi superlegure Nimonik 263 su mehanički obrađeni pikosekundnim laserom, u dve grupe: prva grupa osnovni materijal, i druga grupa laserom zavareni spojevi. $U$ ovom radu su limovi superlegure Nimonic 263, debljine $2 \mathrm{~mm}$ zavareni bez dodatnog materijala u dva prolaza. Limovi su zavareni $\mathrm{Nd}$ :.YAG laserom koji ima raznih prednosti u odnosu na $\mathrm{CO}_{2}$ tipove lasera, kao što su visok stepen apsorpcije energije usled male refleksije, visoke brzine zavarivanja i drugo.

\section{Eksperiment}

Uzorci superlegure Nimonik 263, pripremljeni u obliku limova dimenzija $10 \mathrm{~mm}$ x $50 \mathrm{~mm} \times 2 \mathrm{~mm}$, polirani su i očišćeni etanolom. Hemijski sastav Nimonik 263 je naveden u Tabeli 1.

\begin{tabular}{|c|c|c|c|c|c|c|c|c|c|c|c|}
\hline Element & $\mathrm{C}$ & $\mathrm{Si}$ & $\mathrm{Mn}$ & $\mathrm{Al}$ & $\mathrm{Co}$ & $\mathrm{Cr}$ & $\mathrm{Cu}$ & $\mathrm{Fe}$ & $\mathrm{Mo}$ & $\mathrm{Ti}$ & $\mathrm{Ni}$ \\
\hline$\%$ & 0.06 & 0.3 & 0.5 & 0.5 & 20 & 20 & 0.1 & 0.5 & 5.9 & 2.2 & 49.94 \\
\hline
\end{tabular}

Tabela 1. Hemijski sastav superlegure Nimonik 263

Eksperiment se sastojao iz dva dela: u prvom delu osnovni materijal superlegure Nimonik 263 je mehanički obrađen pikosekundnim laserom, a drugom delu su laserski zavareni spojevi mehanički obrađeni pikosekundnim laserom.
U oba dela eksperimenta uzorci su premazani crnom bojom (zaštitnim slojem) i uronjeni $u$ destilovanu vodu, koja je služila kao transparentni sloj. Laserski zrak je vođen sistemom ogledala i fokusiran ispod površine uzorka, pod upadnim uglom od 90 stepeni. Šema eksperimenta za LSP obradu Nimonic 263 uzoraka prikazana je na slici 1.

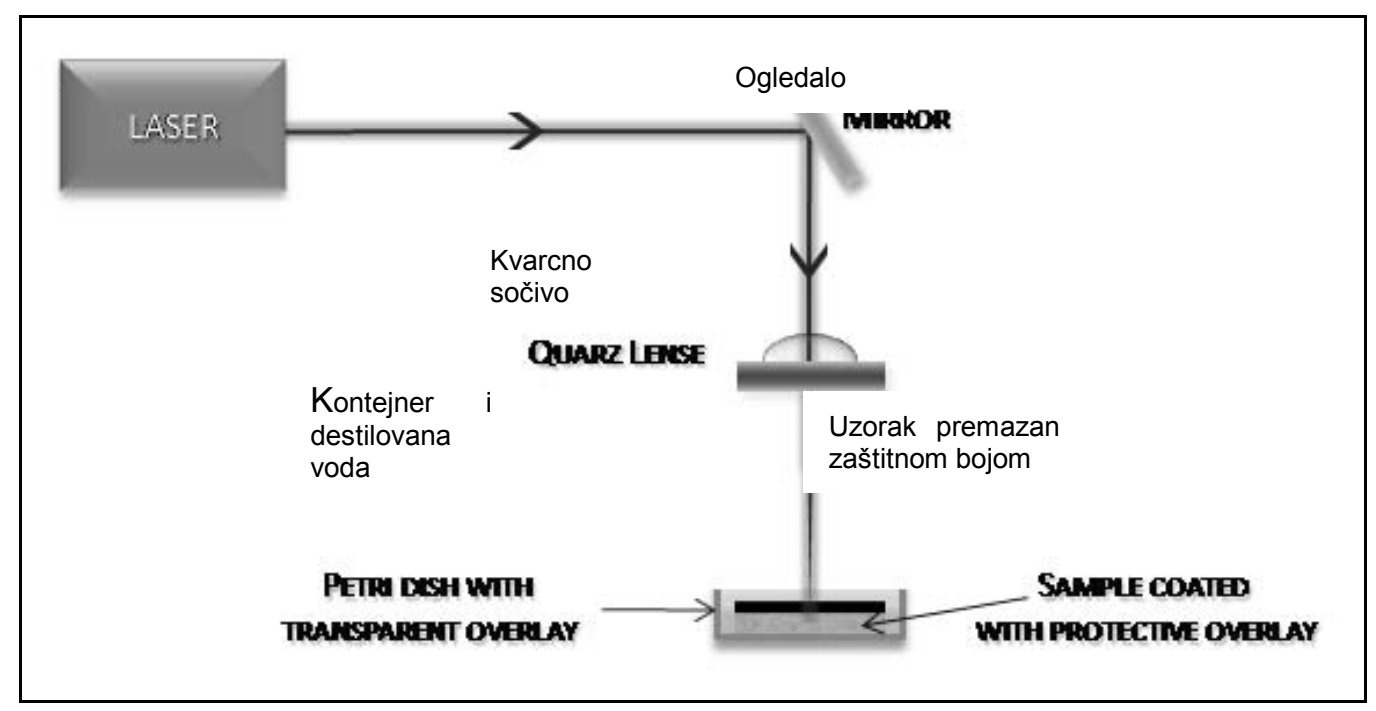

Slika 1. Šema eksperimenta za mehaničku obradu laserom superlegure Nimonik 263.

Uzorci osnovnog materijala su laserski obrađeni sledećim parametrima procesa: trajanje impulsa 170 ps, talasna dužina impulsa $1064 \mathrm{~nm}$ i broj impulsa od 50,100 i 200. Tip lasera je Nd: YAG EKSPLA, model SL212P. Energija impulsa je varirala od $2 \mathrm{~mJ}$ do $15 \mathrm{~mJ}$ i odgovarajuća gustina energije se kretala od 0,1 do $0,3 \mathrm{~J} / \mathrm{cm}^{2}$. Dobijene površinske promene su proučavane skenirajućim elektronskim mikroskopom, SEM Model JEOL JSM-5800. Merenja mikrotvrdoće su obavljena po Vickersu pomoću poluautomatskog aparata Hauser 249A i pod opterećenjem od 10 N. Takođe, morfologija promene površine je analizirana beskontaktnim profilometrom ZIGO NevViev 7100.
Uzorci superlegure Nimonic 263 su zavareni $\mathrm{Nd}$ : YAG parametrima: energija lasera $250 \mathrm{~A}$, trajanjem impulsa od $8,0 \mathrm{~ms}$, veličina spota od $1,0 \mathrm{~mm}$, i frekvencija impulsa od $4,0 \mathrm{~Hz}$. Zavareni spojevi su podvrgnuti mehaničkoj obradi pikosekundnim gore navedenim laserom sa sledećim karakteristikama: talasna dužina $1064 \mathrm{~nm}$, trajanje impulsa $170 \mathrm{PS}$, režim oko TEM00, frekvencija $10 \mathrm{~Hz}$.Energija impulsa je 2 - 15 mJ. Ispitivanjem zatezanjem su određene zatezne karakteristike uzoraka a ispitivanja su obavljena na mašini Shimadzu kapaciteta 250 kN. Uzorci su snimani na SEM i analizirani energo-disperzoionom spektrometrijom. 


\section{Rezultati i diskusija}

Mikrostruktura osnovnog materijala superlegure Nimonik 263 je prikazana na slici 2. Mikrostrukturu karakterišu veličina zrna $\mathrm{Fm}=232.45 \mu \mathrm{m}^{2}$, slika 2,
[14]. Mera površine odstupanja devijacije površine je odnos gornjeg i donjeg vrha (peak to valley - PV odnos) i iznosi $48,5 \mu \mathrm{m}$ za osnovni materijal superlegure Nimonik 263.
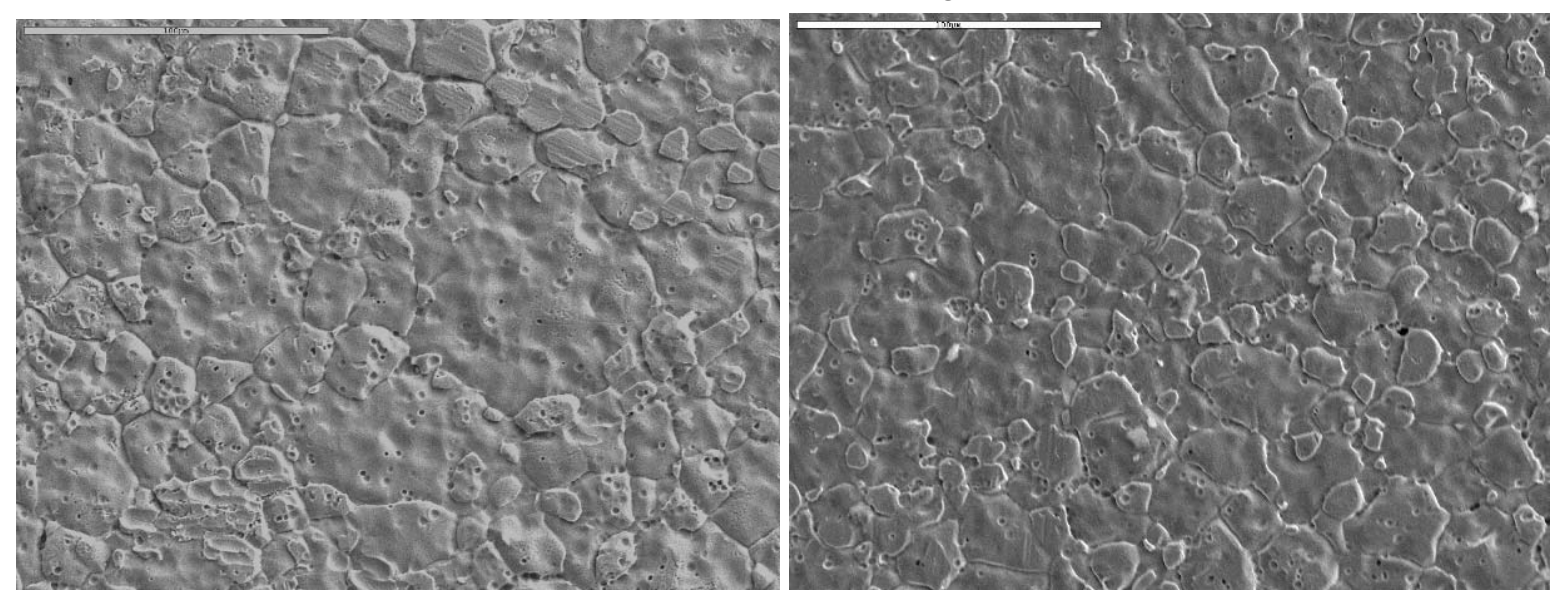

Slika 2. a) Mikrostruktura superlegure Nimonik 263. SEM ; b) posle mehaničke obrade laserom (energija impulse od $10 \mathrm{~mJ}(F=$ $0.2 \mathrm{~J} \mathrm{~cm}^{-2}$ ) i talasna dužina od $1064 \mathrm{~nm}$.

Interakcija pikosekundog laserskog impulsa sa metalima je složen proces, [15], jer se radi o nekoliko fizičkih procesa i zavisi od parametara lasera (talasne dužine, trajanje impulsa, energije itd) i površinskog stanja uzorka (hrapavost, koeficijent apsorpcije itd). Baziran na ovom ograničenom ablacionom modu proces mehaničke obrade laserom se može opisati u dvostepenoj sekvenci: 1) brza ekspanzija plazme stvara iznenadni jednoosni pritisak na ozračenu površinu i diletaciju površinskog sloja, 2) okolni materijal reaguje na deformisane površine stvarajući polje pritisnih napona $[13,16]$.

Udarni talasi izazivaju promene u mikrostrukturi blizu površine i uzrokuju formiranje dislokacija velike gustine. Kombinovani efekat mikrostrukturnih promena i nagomilavanja dislokacija doprinosi povećanju mehaničkih osobina blizu površine. LSP poboljšava zamor, koroziju i otpornost metala kroz mehaničke efekte od udarnih talasa.

Slika 2 b). predstavlja mikrostrukturu nakon procesa mehaničke obrade pikosekundnim laserom na $1064 \mathrm{~nm}$ talasne dužine, impulsa energije od $10 \mathrm{~mJ}$ i broja impulsa 100. Kada se povećava broj akumuliranih impulsa mikrostruktura postaje finija, ali nakon 200 impulsa dolazi do delimičnog topljenje materijala pojavljuje i mikrostruktura postaje staklasta. Povećanjem energije impulsa smanjuje se veličina zrna. Najfinija struktura se dobija pri energiji impulsa od $10 \mathrm{~mJ}$, mada su i pri ovoj energiji primetne pore. Pri većim energijama impulsa veći je broj pora.
Promene u mikrostrukturi, izazvane mehaničkom obradom laserom, su tipične za ovu superleguru i odražavaju se formiranjem karbida - TiC, CrC i ( Ti, Mo) C, koji se odvajaju na zrnima i na granicama zrna. Titan monokarbid (TIC) je veoma tvrd, stabilan i na visokim i na niskim temperaturama. ( $\mathrm{Ti}$ Mo) V je karakteristična strukturna komponenta koja prilično utiče na mehaničke i fizičke osobine materijala [17]. Slika 3a) - c) prikazuje faze nastale tokom pikosekundog LSP sa parametrima procesa: talasna dužina $1064 \mathrm{~nm}, 10 \mathrm{~mJ}$ energija laserskog zraka i broj impulsa 100 (Slika 3a i b). Tabela 2 prikazuje rezultate EDS analize mikrokonstituenata označenih na slici $3 a)-c)$. Ovi rezultati sugerišu formiranje raznih faza, kako željenih, tako i neželjenih - u zavisnosti od njihove morfologije, veličine i mesta pojavljivanja. Prema EDS rezultatima spektruma 1 , kao i morfologije ovih faza - prilično regularna piramida, može se pretpostaviti da je to $\mathrm{Ti}$ karbid. Veličina i mesto formiranja sugerišu da je karbid u Spektrum 1 j neželjena faza koja lako može da izazove stvaranje prslina. Faza prikazana u spektrumu 2. je, prema EDS rezultatima, verovatno TiMo karbid. Ove vrste jedinjenja se odlikuju nepravilnim oblicima i mikrometarskim redom veličine zrna. U tom slučaju, prisustvo TiMo karbida je nepoželjno jer može da izazove stvaranje prslina u materijalu. Na slici 3c) prikazani su mikrokonstintuenti čija je elementarna analiza data u tabeli 2 (spektrum 3). Po morfologiji, mestu nastanka i veličini, kao i prema EDS rezultatima smatra se da su ovo Ti karbidi i u ovom slučaju se smatraju povoljnim. 

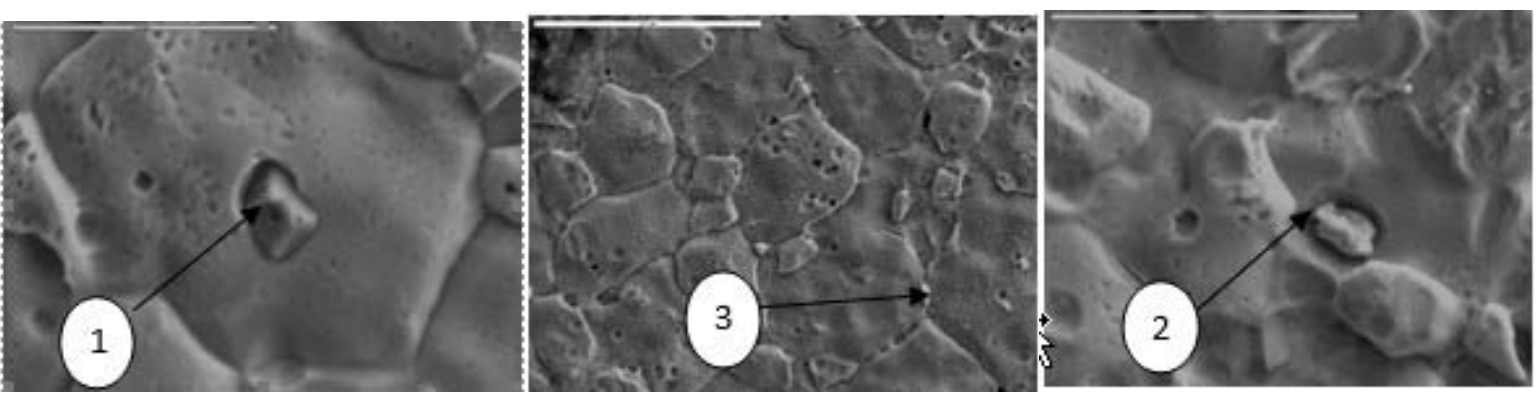

Slika 3. Mikrokonstintuenti formirani tokom mehaničke obrade laserom sledećim parametrima: talasna dužina 1064 nm, energija impulsa od10 mJ, i brojevi impulsa a) 100, b) 100p, c) 50p

\begin{tabular}{|ccccccccccc|}
\hline Spect & $\mathbf{C}$ & $\mathbf{A l}$ & $\mathbf{S i}$ & $\mathbf{T i}$ & $\mathbf{C r}$ & $\mathbf{M n}$ & $\mathbf{F e}$ & Co & Ni & Mo \\
\hline Spec1 & 11.79 & 0.11 & 0.15 & 49.87 & 6.96 & 0.20 & 0.19 & 7.41 & 18.79 & 4.52 \\
\hline Spec 2 & 14.56 & 0.13 & 0.19 & 13.36 & 11.56 & 1.00 & 0.33 & 13.22 & 34.04 & 12.19 \\
\hline Spec 3 & 9.76 & 0.12 & 0.15 & 24.56 & 13.96 & 0.5 & 0.2 & 15.23 & 30.92 & 4.92 \\
\hline
\end{tabular}

Tabela 2. Rezultati EDS analize u tačkama 1, 2 i 3 na slici 3.

U ovom radu, lasersko zavarivanje Nimonic 263 limova je izvršeno različitim parametrima. Parametri koji su obezbedili zavarene spojeve bez grešaka su određeni radiografskim snimanjem. Nakon zavarivanja primenjena je mehanička obrada laserom u cilju dodatnog poboljšanja mehaničkih svojstva i morfologije površine. Slike 4a) i 4b) pokazuju mikrostrukture loma zavarenog spoja Nimonic 263 superlegure nakon ispitivanja zatezanjem. Kao što se očekivalo, svi uzorci su polomljeni u šavu metala zbog činjenice da je zavarivanje izvršeno bez dodatnog materijala. Takođe, mehaničke karakteristike zavarenih spojeva mogu se razlikovati od osnovnog materijala zbog nehomogene distribucije taloženja sekundarnih faza u zavarenim spojevima, kao i zbog mikrosegregacije $u$ interdendritnim oblastima. Vizuelnom observacijom mikrografija, uočava se da je površina preloma dosta ravnomerna sa

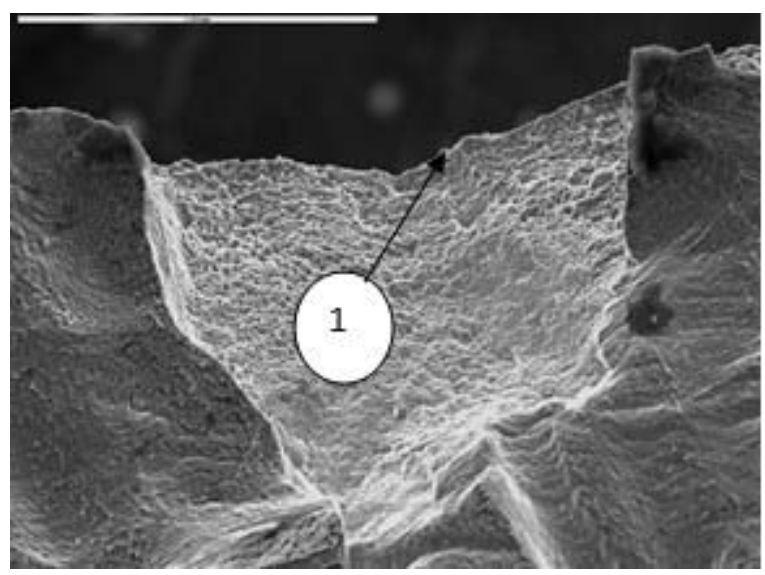

a) jamicama veličine do $2 \mu \mathrm{m}$. Jamice ukazuju na izvesnu duktilnost zavarenog spoja. Na prelomu se ne vidi preferencijalni put loma, a mogu se i jasno uočiti manje čestice. Rupičasti prelom ne ukazuje na postojanje zazora. $U$ tabeli 3 navedeni su rezultati energodisperzivne spektrometrije u mestima označenim na slikama 4a) i 4b). Rezultati pokazuju povećan sadržaj Al. Veličina i morfologija sugerišu formiranje Al oksida. Postojanje ovih čestica na površini loma sugerišu da su mikro šupljine počele na granici čestica/matrica. Rezultati testova zatezne čvrstoće pokazuju da su se prelomi dogodili u zavarenim šavovima. Zatezna čvrstoća je $432 \mathrm{MPa}$, što je oko $85 \%$ od vrednosti zatezne čvrstoće osnovnog materijala. Razlog za to može se naći u različitim morfologijama spajanja tokom procesa zavarivanja laserom [18] i formiranja čestica primećenih u mikroporama.

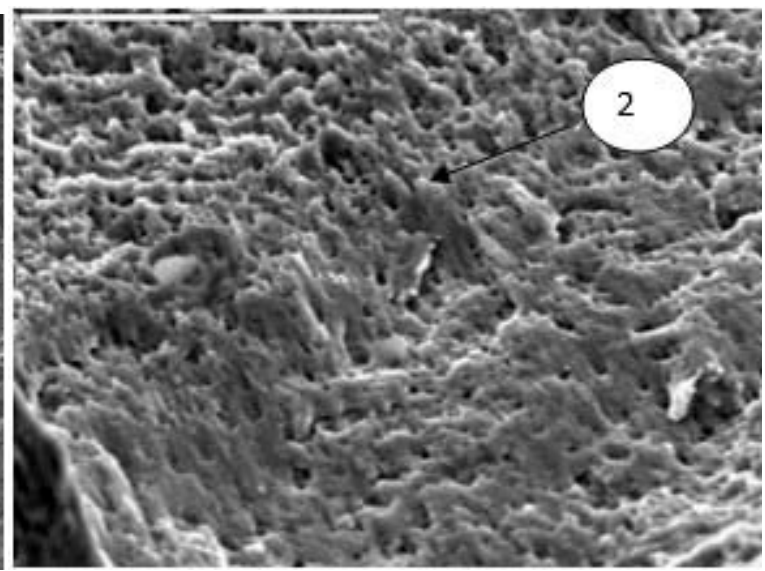

b)

Slika 4. Mikrostrukture prelomnih površina zavarenog spoja Nimonik 263 legure. 


\begin{tabular}{|cccccccccc|}
\hline Spect & $\mathrm{Al}$ & $\mathrm{Si}$ & $\mathrm{Ti}$ & $\mathrm{Cr}$ & $\mathrm{Mn}$ & $\mathrm{Fe}$ & $\mathrm{Co}$ & $\mathrm{Ni}$ & Mo \\
\hline Spec1 & 15.9 & 0.77 & 1.93 & 14.02 & 0.6 & 0.42 & 18.52 & 42.35 & 4.52 \\
\hline Spec 2 & 5.71 & 0.79 & 2.38 & 17.13 & 0.52 & 0.33 & 18.95 & 47.15 & 6.31 \\
\hline
\end{tabular}

Tabela 3. Rezultati EDS analize u tačkama 1 i 2 na slikama 4a) / 4b)

Slika 5a) prikazuje površinu preloma zavarenih spojeva podvrgnutih tretmanu mehaničke laserske obrade posle zavarivanja. Površina loma je manje uniformna od površine loma netretiranog zavarenog spoja. Postoje jamice koje ukazuju na duktilnost loma, ali je njihov oblik više elipsoidan. Njihova veličina je do 7 um. To je u skladu sa rezultatima ispitivanja zatezanjem- zatezna čvrstoća uzorka mehanički tretiranog laserom je $442 \mathrm{MPa}$ - vrlo slično netretiranom uzorku, ali je izduženje kod mehanički tretiranog uzorka oko tri puta veće nego izduženje kod netretiranog uzorka. Slika 5b) prikazuje prednju stranu zavarenog spoja naknadno mehanički obrađenu laserom. Može da se primeti da je posle ispitivanja zatezanjem $u$ prvom sloju, nastalom tokom mehaničke obrade laserom, došlo do usitnjavanja i raspadanja prvog sloja na sitne pločice. Pločice su veoma slične po obliku i geometriji, kao i veličini. Veličina ovih lamela je do $10 \mathrm{pm}$. U tabeli 4 prikazani su rezultati celog područja predstavljenog na slici 5b). Povećani sadržaj Al i Ti ukazuju na formiranje različitih faza. Prema veličini i obliku, i rezultatima u tabeli 4. pretpostavlja se da je došlo do formiranja Ti karbida i Al-oksida.

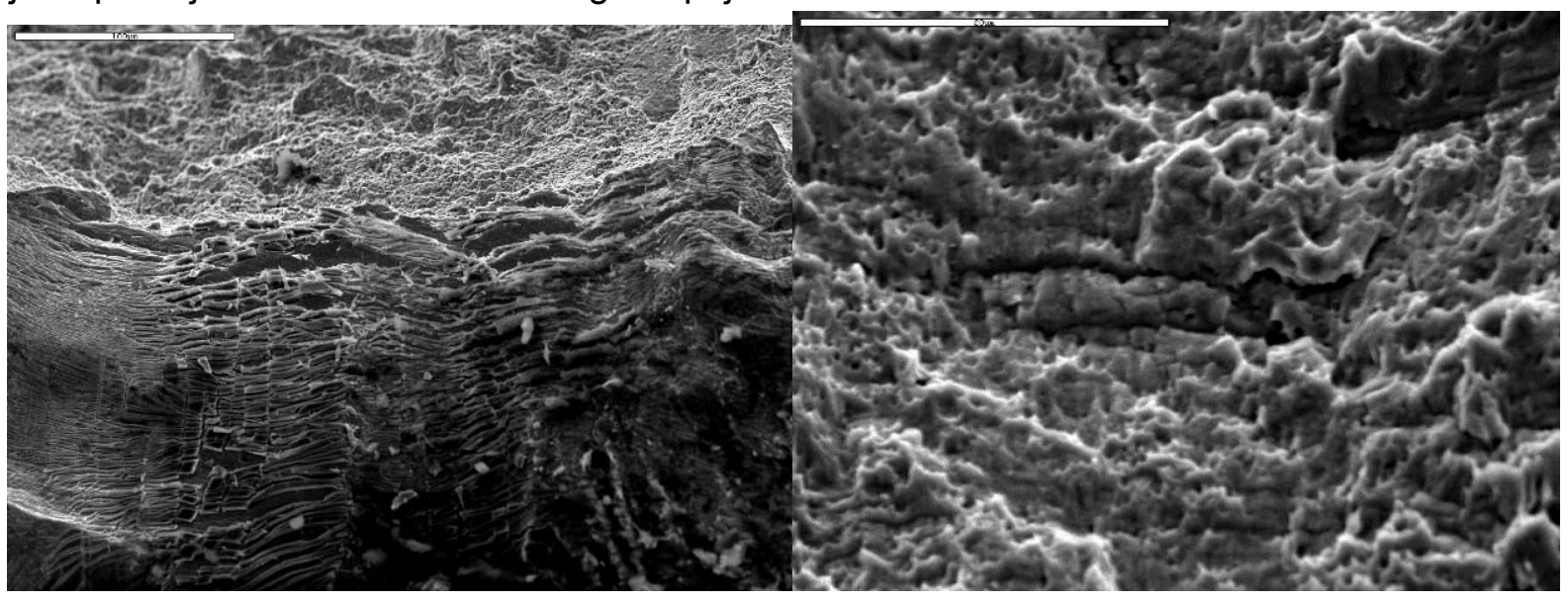

Slika 5. a) Microstruktura prelomne površine naknadno mehanički obrađenog zavarenog spoja Nimonik 263 legure;

b) mikrostruktura prednje strane površine naknadno mehanički obrađenog zavarenog spoja Nimonik 263 legure

\begin{tabular}{|cccccccccc|}
\hline Spect & $\mathrm{Al}$ & $\mathrm{Si}$ & $\mathrm{Ti}$ & $\mathrm{Cr}$ & $\mathrm{Mn}$ & $\mathrm{Fe}$ & $\mathrm{Co}$ & $\mathrm{Ni}$ & $\mathrm{Mo}$ \\
\hline Slika $5 \mathrm{~b})$ & 6.2 & 0.35 & 9.52 & 16.94 & 0.6 & 0.48 & 18.23 & 412.33 & 5.72 \\
\hline
\end{tabular}

Tabela 4. Rezultati eds analize površine prikazane na slici 5b)

Morfologija površine je od velikog značaja za rad raznih delova mašina. Površinska hrapavost ukazuje da površina nije perfektno ravna i prema tome, koncentracije napona malih veličina mogu da se pojave duž površine materijala. Usled opterećenja usled zamora prsline uvek nastaju na slobodnim površinama. Visoka površinska hrapavost stvara koncentraciju lokalnih napona i ubrzava stvaranje prslina.Kod primene materijala za delove gde se traži otpornost na habanje neophodno je ukloniti hrapavu površinu [18]

$\mathrm{Na}$ slikama 6a), 6b) i 6c) prikazani su dvodimenzionalni profili površina posle a) mehaničke obrade laserom osnovnog materijala, b) posle zavarivanja laserom i c) posle mehaničke obrade laserom laserski zavarenog spoja. Analizom slike 6a) dolazi se do zaključka da je mehanička obrada laserom smanjila odnos gornjeg I donjeg vrha (PV odnos) čak 10 puta. Takođe, srednja hrapavost je umanjena dva puta. Rezultati na slikama 6b) i 6c) pokazuju da PV odnos je 374,15 $\mu \mathrm{m}$, i srednja hrapavost je $31,3 \mu \mathrm{m}$, zavarenog spoja bez naknadne obrade. Rezultati izmereni na zavarenom spoju naknadno mehanički obrađenog laserom pokazuju da PV odnos je 316,15 $\mu \mathrm{m}$, koren srednje kvadratne (RMS) je 32,58 $\mu \mathrm{m}$ i prosečna hrapavost je $29,15 \mu \mathrm{m}$. Može se primetiti da je naknadna mehanička obrada laserom zavarenih spojeva izazvala relativno homogenu modifikaciju površine u celoj oblasti interakcije. 

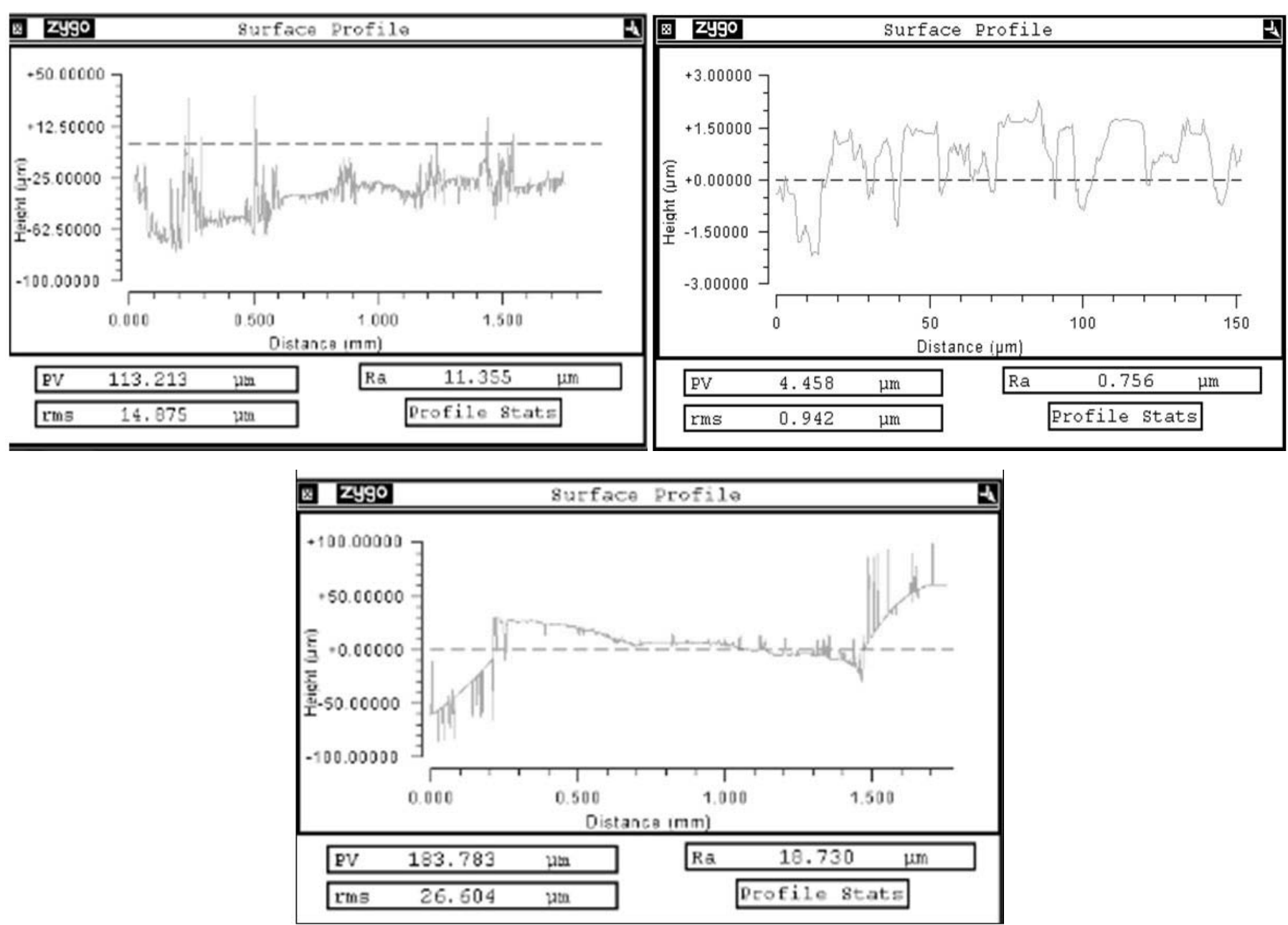

Slika 6. Dvodimenzionalni profili: a) LSP osnovnog materijala, b) zavarenog spoja c) LSP zavarenog spoja.

Mikrotvrdoća je merena po Vikersu, pod opterećenjem od $10 \mathrm{~N}$ za vreme utiskivanja od 10 sec. Mikrotvrdoća osnovnog materijala je iznosila 238,1 HV1, dok je mikrotvrdoća laserom mehanički obrađenog osnovnog materijala iznosila 260 HV1. Nakon laserskog zavarivanje mikrotvrdoća je povećana, tako da je u zoni uticaja toplote izmerena vrednost 248 HV1, dok je u zavarenom spoju vrednost 258 HV1. Mehanička obrada laserom povećava mikrotvrdoću površine osnovnog materijala. Međutim, kod laserom zavarenih spojeva, mehanička obrada povećava mikrotvrdoću u samom šavu dok u zoni uticaja toplote nema bitnih promena i uticaja.

\section{Zaključak}

Mehanička obrada laserom poboljšava kvalitet površina, povećava mikrotvrdoću i izaziva povoljne mikrostrukture transformacije, koje teoretski ukazuju na moguća poboljšanja mehaničkih karakteristika i zamor. Usled mehaničke obrade laserom dolazi do mikrostrukturnih promena i stvaraju se poželjne i nepoželjne faze.
Zavarivanje laserom je dalo zadovoljavajuće rezultate u pogledu mehaničkih osobina s obzirom da je zavarivanje rađeno bez dodatnog materijala. Prelomne površine su uniformne, jamičaste što ukazuje na duktilnost zavarenog spoja.

Mehaničkom obradom zavarenog spoja smanjena je hrapavost i odnos gornjih i donjih pikova. Povećana je mikrotvrdoća i osnovnog materiijala i zavarenog spoja. Nakon mehaničke obrade zavarenog spoja izdvojio se sloj po površini koji se prilikom ispitivanja zatezanjem rasparčao u pločice pravilnh oblika.

\section{Zahvalnost}

Rad je proizašao iz projekata ministarstva za prosvetu, nauku i tehnološki razvoj TR35460, TR35024 i ON 172019. 


\section{Literatura}

[1] Murthy, G.V.S., Ghosh, S., Das, M., Das, G., Ghosh, R.N.:Correlation between ultrasonic velocity and indentation-based mechanical properties with microstructure in Nimonic 263, Material Science and Technology:A 488 (1-2), (2008), 398-405.

[2] Pollock,M.T., Tin,S.: Nickel-Based Superalloys for Advanced Turbine Engines: Chemistry, Microstructure, and Properties, Journal of propulsion and power, 22 (2), (2006), 361-374.

[3] Petronic, S., Kovacevic, A.G., Milosavljevic, A., Sedmak, A.: Microstructural changes of Nimonic 263 superalloy caused by laser beam action. Physica Scripta, T150, (2012), 014080 - 014084.

[4] Liu,X.B., Yu, G., Pang,M., Fan,J.W., Wang, H.H., Zheng, C.Y.: Dissimilar autogenous full penetration welding of superalloy $\mathrm{K} 418$ and 42CrMo steel by a high power CW Nd:YAG laser, Applied Surface Science 253, (2007), 7281-7289.

[5] Jeon, M., Lee, J.H., Woo, T.K., Kim, S.: Effect of Welding and Post-weld Heat Treatment on Tensile Properties of Nimonic 263 at Room and Elevated Temperatures, Metallurgical and materials transactions A, 42A, (2011), 974-985.

[6] Odabası, A., Unlu, N., Goller, G., Kayalı, E.S., Eruslu, M.N.:Assessment of the effects of heat input on microstructure and mechanical properties in laser beam welded Haynes 188 undermatched joints, Materials Science \& Engineering A 559, (2013), 731-741.

[7] Guo, W., Dong, S., Guo, W., Francis, J.A., Li, L.:Microstructure and mechanical characteristics of a laser welded joint in SA508 nuclear pressure vessel steel, Materials Science and Engineering $A$, 625, (2015), 65-80.

[8] Buckson, R.A., Ojo, O.A.: Analysis of the Influence of Laser Welding on Fatigue Crack Growth Behavior in a Newly Developed NickelBase Superalloy Journal of Materials Engineering and Performance, 25, 2014,
[9] Clauer, A.H., Holbrook, J.H., Fairand, B.P.: Effects of laser induced shock waves, In: M.A.Meyers, L.E. Murr (ed), Shock Waves and High-strain, Phenomena in Metals, Plenum Press, New York, (1998), 675-703.

[10] Petronic, S., Milovanovic, D., Milosavljevic, A., Momcilovic, M., Petrusko, D.: Influence of picosecond laser irradiation on nickel-based superalloy surface microstructure, Physica Scripta, T149, (2012), 014079- 014083.

[11] Hong, Z., Chengye,Y.; Laser shock processing of 2024-T62 aluminum alloy, Materials Science and Engineering A257, (1998), 322-327.

[12] Yilbas, B.S., Shuja, S.Z., Arif, A., Gondal, M.A.: Laser-shock processing of steel, J Mater Proc Technol, 135, (1), (2003), 6-17.

[13] Peyre, P., Fabbro, R.: Laser shock processing: a review of the physics and applications, Opt. Quant. Electr. 27 (12), 1995.

[14] Schumann, H.: Metallographie, Leipzig: Deutscher Verlag fuer Grundstoffindustrie, (in German), (1974),

[15] Bauerle, D.: Laser Processing and Chemistry, Springer Verlag, Berlin, (2003). 13-256.

[16] Devaux, D., Fabbro, R., Tollier, L., Bartnicki, E.: Generation of shock waves by laser-induced plasma in confined geometry, J. Appl. Phys. 74 (4), (2012), 2268-2273.

[17] Jang, J. H., Lee,C.H., Heo,Y.U., Suh, D.H.: Stability of $(\mathrm{Ti}, \mathrm{M}) \mathrm{C}(\mathrm{M}=\mathrm{Nb}, \mathrm{V}, \mathrm{Mo}$ and $\mathrm{W})$ Carbide in Steels using First-Principles Calculations, Acta Materialia 60, (2012), 208-217.

[18] Sahaya Grinspan, A., Gnanamoorthy, R.: Surface modification by oil jet peening in Al alloys, AA6063-T6 and AA6061-T4 Part 2: Surface morphology, erosion, and mass loss. Applied Surface Science, 253, ( 2), (2006), 997-1005. 